\title{
The Impact of Sustainable Development Report on Firm Performance in Thailand
}

\author{
Sathaya Thanjunpong \\ Maejo University \\ Thatphong Awirothananon* \\ Maejo University \\ Patyot Dechsiri \\ Maejo University
}

This paper examines the impact of sustainable development report (hereafter called SDR) on firm performance (hereafter called FP) in the Stock Exchange of Thailand on the year 2016. The questionnaires of Global Report Initiative are used for evaluation of SDR, while the FP is measured by both market and accounting performances. This paper finds that the relationship between SDR and FP is significantly positive for excellent corporate governance firms. The results are useful to regulators since they could make decisions about adjust regulations or give some incentives to encourage listed firms to perform better corporate governance and sustainable development practices.

\section{INTRODUCTION}

Both internal and external factors drive firm performance (hereafter called FP). These factors, for example, are behavioural and sociological paradigms, information technology and product innovation, and corporate governance (hereafter called CG). Recently, CG becomes more important; therefore, many prior papers, including Klapper and Love (2004), Durnev and Kim (2005), Bauer, Frijns, Otten, and Tourani-Rad (2008), Bhagat and Bolton (2008), and Akbar (2014), report a positive relationship between CG and FP. Since a positive relationship is exist, it could be argued that good CG should lead to more corporate social responsibility (hereafter called CSR) and have a positive effect on the FP (Dimitropoulos \& Vrondou, 2015; Eccles, Ioannou, \& Serafeim, 2014; Goyal, Rahman, \& Kazmi, 2013; Singal, 2014). Corporate social responsibility (hereafter called CSR) in Thailand particularly seems to have become more important. The Stock Exchange of Thailand (hereafter called SET) has, for example, established the Corporate Governance Centre in 2002 to help listed firms develop their CG system by complying with international assessment regarding the improvement of CG (Corporate Governance Center, 2003). Thai listed firms and related organisations consequently become more involved with CSR. This is supported by the additional sections on the disclosure reports and the annual report; however, it is not officially

*Corresponding Author 
required to disclose the CSR section. There is also a significant increase in the number of activities and projects of listed firms.

Sustainable development report (hereafter called SDR) is a report published by a firm about the practice of measuring, disclosing and being accountable for organisational performance from everyday activities of firm, while working toward the goal of sustainable development. This report could provide balanced and reasonable representations of sustainability performance, including both positive and negative contributions. It could be also considered as non-financial reporting or triple bottom line reporting or CSR reporting. The quality of SDR is expected to contribute to the overall value creation in which one of the characteristics of creation is the increase in the FP. Many previous papers show that SDR has a significant impact on the increasing FP (Lo \& Sheu, 2007; Lourenço, Branco, Curto, \& Eugénio, 2012; Wagner, 2010). Lo and Sheu (2007), for example, show that corporate sustainability has a significantly positive effect on market value (Tobin's (1969) Q) in the US listed firms. Wagner (2010) also finds an advertising intensity moderates the association of corporate sustainability performance and economic performance as measured by Tobin's (1969) Q. Lourenço et al. (2012) further show that the corporate sustainability performance has significantly explanatory power for stock prices over the traditional summary accounting measures such as earnings and book value of equity in North American firms. LÓpez, Garcia and Rodriguez (2007), however, report a negative relationship between corporate sustainability and corporate financial performance. Some prior papers, including Swinkels (2012) and Lerskullawat and Prukumpai (2017), additionally show that the SDR is not significant. Swinkels (2012), for instance, reveals that the disclosure of Global Report Initiative (hereafter called GRI) index score, which is developed by the Global Sustainability Standards Board $(2013)^{1}$, has not significant effect on the FP in the US and Canadian listed firms. Lerskullawat and Prukumpai (2017) further show that there are no differences in performance between the Thai Sustainability Investment firms and the matched ones in the Thai listed firms. In addition, several papers, including Kang and Shivdasani (1995), Sanda, Mikailu, and Garba (2010), and Thanjunpong (2015), focus on the relationship between CG and FP. Thanjunpong (2015), for example, investigates the effect of good CG has an impact on the FP for 326 Thai listed firms in the year 2012. The evaluation of good CG is used by the questionnaires of Thai Institute of Directors. The results show that good CG has positive direct and indirect effects on performance, which is measured by Tobin's (1969) Q, through mediation of tax planning. On the other hand, CG is not associated with the FP (Connelly, Limpaphayom, \& Nagarajan, 2012; Price, Román, \& Rountree, 2011). This paper, therefore, aims to search the benefit of CG implementation to the FP by investigating the impact of SDR on the FP of Thai listed firms.

\section{RESEARCH METHODOLOTY}

The population of this paper are listed firms, which exclude 58 financial firms, in the SET on the year 2016. The sample selection technique is done by using purposive sampling method, where the sampling is done in accordance with two criteria as (a) Firms publish financial statements, annual report, Form 56-1 from their website, and SETSMART database and (b) Firms have the sustainable development report for the study period. Based on the mentioned criteria, there are 340 firms those can be sampled. These firms are in seven industries according to SET categorisation. It comprises of (1) agro and food industry 35 firms, (2) consumer products 28 firms, (3) industrials 64 firms, (4) property and construction 75 firms, (5) resources 25 firms, (6) services 82 firms, and (7) technology 31 firms, respectively.

The dependent variables are both market and accounting performances (namely Tobin's (1969) Q and earning per share: EPS). Tobin's (1969) Q is calculated as the natural logarithm of equity market value plus total liabilities for the year divided by the total assets. EPS is also calculated as the natural logarithm of net income less dividends on preferred stock for the year divided by average outstanding shares. Independent variable is SDR measured by the GRI index score. This score is acquired from Form 56-1, SETSMART database, and annual reports. ${ }^{2}$ The inclusion of each attribute is scored on a binary basis as "yes" (included) or "no" (not included). Each "yes" answer is equal to one point and "no" is equal to zero point. This paper also includes control variables that have been shown to have a significant impact on the 
FP (Price et al., 2011; Swinkels, 2012; Thanjunpong, 2015). Firstly, firm size (hereafter called SIZE) is measured by the natural logarithm of total assets. Secondly, financial leverage (hereafter called LEV) is calculated as the percentage of total debt to total assets for the differences in the financial structure of firms. Thirdly, return on assets (hereafter called ROA) is computed by dividing the net profit to total assets as an indicator of FP. In addition, this paper uses capital intensity (hereafter called CAP) by dividing the property, plant, and equipment to total assets as an indicator of firms' technology. CG, which is a dummy variable, is further used to separate between excellent and non-excellent CG firms. ${ }^{3}$ The value of one is given to an excellent CG firm, which has five stars CG, while a non-excellent CG firm, which has less than five stars $C G$, is assigned the value of zero. Multiple regression technique is utilised to determine the relationship between SDR and FP as follows:

$$
\begin{array}{ll}
\text { Model 1: Tobin's Q } & =\beta_{0}+\beta_{1} \mathrm{SRD}_{\mathrm{i}}+\beta_{2} \mathrm{SIZE}_{\mathrm{i}}+\beta_{3} \mathrm{LEV}_{\mathrm{i}}+\beta_{4} \mathrm{ROA}_{\mathrm{i}}+\beta_{5} \mathrm{CAP}_{\mathrm{i}}+\beta_{6} \mathrm{CG}_{\mathrm{i}} \\
\text { Model 2: } \mathrm{EPS}_{\mathrm{i}} & =\beta_{0}+\beta_{1} \mathrm{SRD}_{\mathrm{i}}+\beta_{2} \mathrm{SIZE}_{\mathrm{i}}+\beta_{3} \mathrm{LEV}_{\mathrm{i}}+\beta_{4} \mathrm{ROA}_{\mathrm{i}}+\beta_{5} \mathrm{CAP}_{\mathrm{i}}+\beta_{6} \mathrm{CG}_{\mathrm{i}}
\end{array}
$$

Additionally, this paper divides all firms into two sub-groups (excellent CG and non-excellent CG firms) to examine whether there are any differences in SDR on the FP (namely Tobin's (1969) Q and EPS) among excellent CG firms (Models 3.1 and 4.1) and non-excellent CG firms (Models 3.2 and 4.2).

$$
\begin{array}{ll}
\text { Model 3: Tobin's Q } & =\beta_{0}+\beta_{1} \text { SRD }_{i}+\beta_{2} \text { SIZE }_{i}+\beta_{3} \text { LEV }_{i}+\beta_{4} \text {ROA}_{i}+\beta_{5} \text { CAP }_{i} \\
\text { Model 4: } \text { EPS }_{i} & =\beta_{0}+\beta_{1} \text { SRD }_{i}+\beta_{2} \text { SIZEE }_{i}+\beta_{3} \text { LEV }_{i}+\beta_{4} \text {ROA}_{i}+\beta_{5} \text { CAP }_{i}
\end{array}
$$

\section{RESULTS AND DISCUSSION}

Table 1 presents descriptive statistics for all firms and two sub-samples for excellent and nonexcellent CG firms in the SET, based on Tobin's Q firms. It also reports the values of means and the $t$ statistic that examine mean difference between excellent and non-excellent CG firms for all variables. The descriptive statistics show a mean value of Tobin's $Q$ for all firms of $0.374 \%$, while the mean Tobin's Q for excellent and non-excellent CG firms are $0.498 \%$ and $0.352 \%$, respectively. The results also show that Tobin's $\mathrm{Q}$ is not statistically significant difference between excellent and non-excellent CG firms. The Tobin's Q for excellent CG firms is, however, higher when compared with non-excellent CG firms.

TABLE 1

DESCRIPTIVE STATISTICS BASED ON TOBIN'S Q DATA

\begin{tabular}{lrrrrrrc}
\hline & \multicolumn{2}{c}{$\begin{array}{c}\text { All firms } \\
(n=340)\end{array}$} & \multicolumn{2}{c}{$\begin{array}{c}\text { Excellent CG firms } \\
(n=52)\end{array}$} & $\begin{array}{c}\text { Non-excellent CG firms } \\
(n=288)\end{array}$ & $\begin{array}{c}t \text {-statistic } \\
\text { of mean }\end{array}$ \\
\cline { 2 - 7 } Variables & Mean & \multicolumn{1}{c}{ SD } & Mean & SD & Mean & SD & \multicolumn{1}{c}{ difference } \\
\hline Tobin's Q & 0.374 & 0.639 & 0.498 & 0.999 & 0.352 & 0.549 & 1.518 \\
SRD & 11.590 & 3.055 & 13.960 & 2.686 & 11.170 & 2.923 & $6.422^{* * *}$ \\
SIZE & 22.606 & 1.517 & 24.014 & 1.728 & 22.351 & 1.328 & $6.593^{* * *}$ \\
LEV & 0.439 & 0.251 & 0.497 & 0.156 & 0.428 & 0.264 & $2.585^{* * *}$ \\
ROA & 0.038 & 0.097 & 0.057 & 0.070 & 0.035 & 0.101 & 1.546 \\
CAP & 0.340 & 0.236 & 0.329 & 0.218 & 0.342 & 0.240 & -0.355 \\
CG & 0.153 & 0.360 & & & & & \\
\hline
\end{tabular}

Notes: Tobin's Q is the natural logarithm of equity market value add total liabilities for the year divided by the total assets; SRD is the GRI index score; SIZE is the natural logarithm of total assets; LEV is the percentage of total debt to total assets; ROA is the percentage of net profit to total assets; CAP is the percentage of property, plant, and equipment to total assets; CG has the value of one when a firm has excellent CG scores and zero otherwise; One, two, and three asterisks indicate statistical significance at the 0.10 level, 0.05 level, and 0.01 level, respectively. 
The descriptive statistics in Table 1 show that the average value of SRD for all firms is 11.590, while the mean value for excellent CG firms are 13.960 and 11.170 for non-excellent CG firms. In addition, the $t$-statistic for mean difference of SRD between excellent and non-excellent CG firms is statistical significance. The results show that excellent CG firms have better SRD than non-excellent CG firms do. Additionally, the mean value of SIZE for all firms is 22.606, while the mean value for excellent and nonexcellent CG firms are 24.014 and 22.351, respectively. The results for the $t$-statistic for mean difference between excellent and non-excellent CG firms is statistical significance, which indicates that SIZE for excellent CG firms is greater than in non-excellent CG firms. Moreover, the average value of LEV for all firms is 0.439 , while the mean value for excellent and non-excellent CG firms are 0.497 and 0.428 , respectively. The results for the $t$-statistic for mean difference between excellent and non-excellent CG firms is statistical significance, which indicates that LEV for excellent CG firms is greater than in nonexcellent CG firms. However, the descriptive statistics for ROA for all firms is 0.038 , while the mean value for excellent and non-excellent CG firms are 0.057 and 0.035 , respectively. Furthermore, the mean value of CAP for all firms is 0.034 , while the mean value for excellent and non-excellent CG firms are 0.329 and 0.342 , respectively. The mean value of CG for all firms is 0.153 .

Table 2 presents descriptive statistics for the full and two sub-samples for both excellent and nonexcellent CG firms in the SET, based on EPS data. It also reports the values of mean and the $t$-statistics those examine the mean difference between excellent and non-excellent CG firms for all variables. The descriptive statistics show a mean value of EPS for all firms of $-0.499 \%$, while the mean EPS for excellent and non-excellent CG firms are $0.400 \%$ and $-0.685 \%$, respectively. The results also show that the EPS is statistically significant difference between excellent and non-excellent CG firms. The EPS for excellent CG firms is, however, higher when compared with non-excellent CG firms.

TABLE 2

DESCRIPTIVE STATISTICS BASED ON EPS DATA

\begin{tabular}{lccccccc}
\hline & \multicolumn{2}{c}{$\begin{array}{c}\text { All firms } \\
(n=268)\end{array}$} & \multicolumn{2}{c}{$\begin{array}{c}\text { Excellent CG firms } \\
(n=46)\end{array}$} & $\begin{array}{c}\text { Non-excellent CG firms } \\
(n=222)\end{array}$ & $\begin{array}{c}t \text {-statistic } \\
\text { of mean } \\
\text { difference }\end{array}$ \\
\cline { 2 - 6 } Variables & Mean & SD & Mean & SD & Mean & SD & $3.665^{* * *}$ \\
\hline EPS & -0.499 & 1.870 & 0.400 & 1.504 & -0.685 & 1.887 & $6.422^{* * *}$ \\
SRD & 11.980 & 2.951 & 14.350 & 2.567 & 11.490 & 2.788 & $6.593^{* * *}$ \\
SIZE & 22.764 & 1.511 & 24.191 & 1.724 & 22.469 & 1.280 & $2.585^{* * *}$ \\
LEV & 0.419 & 0.199 & 0.483 & 0.153 & 0.405 & 0.206 & 1.546 \\
ROA & 0.072 & 0.059 & 0.074 & 0.054 & 0.072 & 0.060 & -0.355 \\
CAP & 0.335 & 0.228 & 0.330 & 0.210 & 0.336 & 0.232 & \\
CG & 0.172 & 0.378 & & & & & \\
\hline
\end{tabular}

Notes: EPS is the natural logarithm of net income less dividends on preferred stock for the year divided by average outstanding shares; SRD is the GRI index score; SIZE is the natural logarithm of total assets; LEV is the percentage of total debt to total assets; ROA is the percentage of net profit to total assets; CAP is the percentage of property, plant, and equipment to total assets; CG has the value of one when the firm has excellent CG scores and zero otherwise; One, two, and three asterisks indicate statistical significance at the 0.10 level, 0.05 level, and 0.01 level, respectively.

The descriptive statistics in Table 2 show that the average value of SRD for all firms is 11.980, while the mean value for excellent CG firms is 14.350 and 11.490 for non-excellent CG firms. In addition, the $t$ statistic for mean difference of SRD between excellent and non-excellent CG firms is statistical significance. The results show that excellent CG firms have better SRD than non-excellent CG firms do. Additionally, the mean value of SIZE for all firms is 22.764, while the mean value for excellent and nonexcellent CG firms are 24.191 and 22.469, respectively. The results for the $t$-statistic for mean difference between excellent and non-excellent CG firms is statistical significance, which indicates that SIZE for excellent CG firms is greater than in non-excellent CG firms. Moreover, the average value of LEV for all 
firms is 0.419 , while the mean value for excellent and non-excellent CG firms are 0.483 and 0.405 , respectively. The results for the $t$-statistic for mean difference between excellent and non-excellent CG firms is statistical significance, which indicates that LEV for excellent CG firms is greater than in nonexcellent CG firms. However, the descriptive statistics for ROA for all firms is 0.072 , while the mean value for excellent and non-excellent CG firms are 0.074 and 0.072 , respectively. Furthermore, the mean value of CAP for all firms is 0.335 , while the mean value for excellent and non-excellent CG firms are 0.330 and 0.336 , respectively. The mean values for CG for all firms is 0.172 .

A Pearson product-moment correlation, as shown in Table 3, is computed to examine the correlation among explanatory variables. The coefficient values are between 0.007 and 0.404 . The correlation among variables is relatively low (below \pm 0.700 ), indicating that multicollinearity problem is not exist (Hair, Black, Babin, \& Anderson, 2010). This paper further considers whether data has a normal distribution or not. According to Berenson, Levine and Krehbiel's (2012) statement, the sampling distribution become almost normal, regardless of shape of population since the sample size is large enough ( $n$ is greater than 30). The data of this paper, therefore, has a normal distribution.

TABLE 3

PEARSON CORRELATION MATRIX

\begin{tabular}{|c|c|c|c|c|c|c|c|c|}
\hline Variables & Tobin's Q & EPS & SRD & SIZE & LEV & ROA & CAP & CG \\
\hline Tobin's Q & 1.000 & & & & & & & \\
\hline EPS & $-0.191 * *$ & 1.000 & & & & & & \\
\hline SRD & 0.096 & $0.180 * *$ & 1.000 & & & & & \\
\hline SIZE & -0.069 & $0.151 *$ & $0.354 * *$ & 1.000 & & & & \\
\hline LEV & 0.019 & $-0.180 * *$ & 0.035 & $0.332 * *$ & 1.000 & & & \\
\hline ROA & $0.315 * *$ & $0.404 * *$ & $0.206 * *$ & $0.150 * *$ & $-0.306^{* *}$ & 1.000 & & \\
\hline CAP & $0.141 * *$ & -0.007 & 0.045 & -0.021 & -0.024 & 0.023 & 1.000 & \\
\hline $\mathrm{CG}$ & 0.082 & $0.219 * *$ & $0.330 * *$ & $0.395 * *$ & 0.099 & 0.084 & -0.019 & 1.000 \\
\hline
\end{tabular}

Notes: Tobin's Q is the natural logarithm of equity market value add total liabilities for the year divided by the total assets; EPS is the natural logarithm of net income less dividends on preferred stock for the year divided by average outstanding shares; SRD is the GRI index score; SIZE is the natural logarithm of total assets; LEV is the percentage of total debt to total assets; ROA is the percentage of net profit to total assets; CAP is the percentage of property, plant, and equipment to total assets; CG has the value of one when the firm has excellent CG scores and zero otherwise; One, two, and three asterisks indicate statistical significance at the 0.10 level, 0.05 level, and 0.01 level, respectively.

As previously mentioned, multiple regression technique is used for analysing data and tests for hetero-scedasticity problem. According to the White's (1980) test, all models do not have a problem of hetero-scedasticity. The results in Table 4 show that the coefficient for SDR and FP is not statistically significant. It indicates that firms with good SDR could not achieve a high performance. When dividing all firms into two sub-groups (excellent and non-excellent CG firms), the result indicates that there is no significant relationship between SDR and FP for non-excellent CG firms. On the other hand, the relationship between SDR and FP for excellent CG firms are positively and statistically significant, since $\mathrm{CG}$ are associated with higher disclosure and transparency, higher accounting quality, and audit quality. Good SDR may, therefore, be able to increase the FP. This finding is similar to previous papers, including Klapper and Love (2004), Durnev and Kim (2005), Bauer et al. (2008), Bhagat and Bolton (2008), and Akbar (2014).

Among the control variables, the relationship between SIZE and Tobin's Q is negatively and statistically significant, while the relationship between SIZE and EPS is positively and statistically significant for all firms. These effects are the same regardless of excellent and non-excellent CG firms. Similarly, the effects of LEV on Tobin's Q for all firms and two sub-samples of excellent and nonexcellent CG firms are positively and statistically significant, while the effects of LEV on EPS for all 
firms and non-excellent CG firms are negatively and statistically significant. The effects of ROA on the FP (both Tobin's Q and EPS) are, moreover, positive significance for both excellent and non-excellent CG firms. In addition, the effects of CAP on Tobin's Q for all firms and non-excellent CG firms are positively and statistically significant, while the effect of CAP on EPS for all firms is not statistically significant. The effect will further be the same when divided all firms into excellent and non-excellent CG firms. Finally, the relationship between CG and FP is positively statistical significance.

TABLE 4

EFFECTS OF SUSTATIANABLE DEVELOPMENT REPORT ON FIRM PERFORMANCE

\begin{tabular}{|c|c|c|c|c|c|c|}
\hline \multirow[b]{2}{*}{$\begin{array}{l}\text { Independent } \\
\text { variables }\end{array}$} & \multicolumn{3}{|c|}{ Dependent variable: Tobin's Q } & \multicolumn{3}{|c|}{ Dependent variable: EPS } \\
\hline & $\begin{array}{l}\text { All firms } \\
\text { Model } 1\end{array}$ & $\begin{array}{l}\text { Excellent } \\
\text { CG firms } \\
\text { Model } 3.1\end{array}$ & $\begin{array}{c}\text { Non- } \\
\text { excellent } \\
\text { CG firms } \\
\text { Model } 3.2\end{array}$ & $\begin{array}{l}\text { All firms } \\
\text { Model } 2\end{array}$ & $\begin{array}{l}\text { Excellent } \\
\text { CG firms } \\
\text { Model } 4.1\end{array}$ & $\begin{array}{c}\text { Non- } \\
\text { excellent } \\
\text { CG firms } \\
\text { Model } 4.2\end{array}$ \\
\hline Intercept & $\begin{array}{l}2.250^{* * * *} \\
(0.535)\end{array}$ & $\begin{array}{l}5.069^{* * * *} \\
(1.663)\end{array}$ & $\begin{array}{l}1.241 * * \\
(0.539)\end{array}$ & $\begin{array}{l}-6.496 * * * \\
(1.764)\end{array}$ & $\begin{array}{c}-11.016^{* * * *} \\
(2.644)\end{array}$ & $\begin{array}{l}-4.609 * * \\
(2.183)\end{array}$ \\
\hline SRD & $\begin{array}{c}0.012 \\
(0.012)\end{array}$ & $\begin{array}{l}0.115^{* *} \\
(0.049)\end{array}$ & $\begin{array}{l}-0.001 \\
(0.002)\end{array}$ & $\begin{array}{c}0.046 \\
(0.038)\end{array}$ & $\begin{array}{l}0.217 * * * \\
(0.074)\end{array}$ & $\begin{array}{c}0.016 \\
(0.041)\end{array}$ \\
\hline SIZE & $\begin{array}{l}-0.111^{* * * *} \\
(0.026)\end{array}$ & $\begin{array}{l}-0.308^{* * * *} \\
(0.075)\end{array}$ & $\begin{array}{l}-0.057^{* *} \\
(0.026)\end{array}$ & $\begin{array}{l}0.228^{* * * *} \\
(0.082)\end{array}$ & $\begin{array}{l}0.341^{* * * *} \\
(0.112)\end{array}$ & $\begin{array}{c}0.153 \\
(0.103)\end{array}$ \\
\hline LEV & $\begin{array}{l}0.553^{* * * *} \\
(0.145)\end{array}$ & $\begin{array}{c}1.674^{*} \\
(0.862)\end{array}$ & $\begin{array}{l}0.420^{* * *} \\
(0.131)\end{array}$ & $\begin{array}{l}-1.613^{* * * *} \\
(0.588)\end{array}$ & $\begin{array}{l}-1.227 \\
(1.292)\end{array}$ & $\begin{array}{l}-1.400 * * \\
(0.661)\end{array}$ \\
\hline $\mathrm{ROA}$ & $\begin{array}{l}2.622 * * * \\
(0.362)\end{array}$ & $\begin{array}{l}6.063^{* * * *} \\
(1.897)\end{array}$ & $\begin{array}{l}2.255^{* * *} \\
(0.329)\end{array}$ & $\begin{array}{l}11.548^{* * *} \\
(1.809)\end{array}$ & $\begin{array}{l}10.736^{* * * *} \\
(3.588)\end{array}$ & $\begin{array}{l}12.261 * * * \\
(2.036)\end{array}$ \\
\hline CAP & $\begin{array}{l}0.355^{* * *} \\
(0.134)\end{array}$ & $\begin{array}{c}0.136 \\
(0.548)\end{array}$ & $\begin{array}{l}0.369^{* * *} \\
(0.124)\end{array}$ & $\begin{array}{l}-0.056 \\
(0.445)\end{array}$ & $\begin{array}{l}-0.464 \\
(0.855)\end{array}$ & $\begin{array}{l}-0.016 \\
(0.485)\end{array}$ \\
\hline $\mathrm{CG}$ & $\begin{array}{l}0.205^{* *} \\
(0.098)\end{array}$ & & & $\begin{array}{l}0.657 * * \\
(0.306)\end{array}$ & & \\
\hline F-value & $12.232 * * *$ & $5.266^{* * *}$ & $11.659 * * *$ & $14.334 * * *$ & $6.563 * * *$ & $10.868 * * *$ \\
\hline $\mathrm{R}^{2}$ & 0.181 & 0.364 & 0.171 & 0.248 & 0.451 & 0.201 \\
\hline Adjusted $\mathrm{R}^{2}$ & 0.166 & 0.295 & 0.157 & 0.231 & 0.382 & 0.183 \\
\hline
\end{tabular}

Notes: Tobin's Q is the natural logarithm of equity market value add total liabilities for the year divided by the total assets; EPS is the natural logarithm of net income less dividends on preferred stock for the year divided by average outstanding shares; SRD is the GRI index score; SIZE is the natural logarithm of total assets; LEV is the percentage of total debt to total assets; ROA is the percentage of net profit to total assets; CAP is the percentage of property, plant, and equipment to total assets; CG has the value of one when the firm has excellent CG scores and zero otherwise; Standard errors are given in parentheses; One, two, and three asterisks indicate statistical significance at the 0.10 level, 0.05 level, and 0.01 level, respectively.

\section{CONCLUSION}

This paper investigates the impact of SDR on the FP of listed firms, which exclude 58 financial firms, in the SET. The sample size consists of 340 firms, based only on the year 2016. The questionnaires of GRI are used for evaluation of SDR. The FP is also measured by both market and accounting performances (namely Tobin's (1969) Q and EPS). This paper finds that the SDR has no effects on the FP. Regarding control variable, the CG has positive effects on the FP. Moreover, the relationship between SDR and FP is significantly positive for excellent CG firms. The relationship is, however, weak and insignificant for non-excellent CG firms. Since the results are obtained from only one year of data, this implies that the FP would benefit from SDR over longer period (e.g., three years or more). 
The results are useful to the SET and the Securities and Exchange Commission (hereafter called SEC). They could further make decisions about adjust regulations or give incentives to encourage Thai listed firms to perform better CG and SDR practices. Market regulators (both SET and SEC), for example, should focus on non-excellent CG firms and encourage them to improve their CG and SDR practices by giving them incentive to, as the results indicate that the relationship between SDR and FP for excellent CG firms are positively significant.

\section{ENDNOTES}

1. The GRI index score is calculated from 18 separate criteria to quantify the overall of GRI principles from the Global Sustainability Standards Board (2013). The scorecard criteria span three sections of the GRI principles: Economic indicators have five criteria, environmental indicators have nine criteria, and social indicators have four criteria.

2. This score is adjusted to consider the subtleties of Thai laws and regulations.

3. This score is announced by the Thai Institute of Directors and calculated from 148 separate criteria to quantify the overall of Corporate Governance Principles from Organisation of Economic Co-operation and Development (2004). The scorecard criteria span five sections: the rights of shareholders (25\%), equitable treatment of shareholders (15\%), role of stakeholders $(10 \%)$, disclosure and transparency $(25 \%)$, and board responsibilities $(25 \%)$.

\section{REFERENCES}

Akbar, A. (2014). Corporate governance and firm performance: Evidence from textile sector of Pakistan. Journal of Asian Business Strategy, 4(12), 200-207.

Bauer, R., Frijns, B., Otten, R., \& Tourani-Rad, A. (2008). The impact of corporate governance on corporate performance: Evidence from Japan. Pacific-Basin Finance Journal, 16(3), 236-251.

Berenson, M. L., Levine, D. M., \& Krehbiel, T. C. (2012). Basic Business Statistics: Concept and Application (12th ed.). New Jersey: Pearson Education.

Bhagat, S., \& Bolton, B. (2008). Corporate governance and firm performance. Journal of Corporate Finance, 14(3), 257-273.

Connelly, J. T., Limpaphayom, P., \& Nagarajan, N. J. (2012). Form versus substance: The effect of ownership structure and corporate governance on firm value in Thailand. Journal of Banking \& Finance, 36(6), 1722-1743.

Corporate Governance Center. (2003). Good Governance Assessment of Listed Companies. Bangkok: The Stock Exchange of Thailand.

Dimitropoulos, P. E., \& Vrondou, O. (2015). Corporate social responsibility and firm value in the sport recreation sector: A review. Business Management and Strategy, 6(2), 28-43.

Durnev, A., \& Kim, E. H. (2005). To steal or not to steal: Firm attributes, legal environment, and valuation. Journal of Finance, 60(3), 1461-1493.

Eccles, R. G., Ioannou, I., \& Serafeim, G. (2014). The impact of corporate sustainability on organizational processes and performance. Management Science, 60(11), 2835-2857.

Global Sustainability Standards Board. (2013). G4 Sustainability Reporting Guidelines. Amsterdam: Global Reporting Initiative.

Goyal, P., Rahman, Z., \& Kazmi, A. A. (2013). Corporate sustainability performance and firm performance research. Management Decision, 51(2), 361-379.

Hair, J. F., Black, W. C., Babin, B. J., \& Anderson, R. E. (2010). Multivariate Data Analysis (7th ed.). New Jersey: Pearson Education.

Kang, J.-K., \& Shivdasani, A. (1995). Firm performance, corporate governance, and top executive turnover in Japan. Journal of Financial Economics, 38(1), 29-58.

Klapper, L. F., \& Love, I. (2004). Corporate governance, investor protection, and performance in emerging markets. Journal of Corporate Finance, 10(5), 703-728. 
Lerskullawat, P., \& Prukumpai, S. (2017). Sustainable development and firm performance: Evidence from Thailand. International Journal of Management and Applied Science, 3(12), 46-49.

Lo, S.-F., \& Sheu, H.-J. (2007). Is corporate sustainability a value-increasing strategy for business? Corporate Governance: An International Review, 15(2), 345-358.

López, M. V., Garcia, A., \& Rodriguez, L. (2007). Sustainable development and corporate performance: A study based on the Dow Jones Sustainability Index. Journal of Business Ethics, 75(3), 285300.

Lourenço, I. C., Branco, M. C., Curto, J. D., \& Eugénio, T. (2012). How does the market value corporate sustainability performance? Journal of Business Ethics, 108(4), 417-428.

Organisation for Economic Co-operation and Development. (2004). OECD Principles of Corporate Governance. Paris: OECD.

Price, R., Román, F. J., \& Rountree, B. (2011). The impact of governance reform on performance and transparency. Journal of Financial Economics, 99(1), 76-96.

Sanda, A. U., Mikailu, A. S., \& Garba, T. (2010). Corporate governance mechanisms and firms' financial performance in Nigeria. Afro-Asian J. of Finance and Accounting, 2(1), 22-39.

Singal, M. (2014). The link between firm financial performance and investment in sustainability initiatives. Cornell Hospitality Quarterly, 55(1), 19-30.

Swinkels, E. (2012). The Effect of Publishing a GRI Sustainabilit Report on Financial Performance. Tiburg University, Netherlands.

Thanjunpong, S. (2015). Good corporate governance effects on performance through mediation of tax planning of listed companies in the Stock Exchange of Thailand. Journal of the Association of Researchers, 20(2), 105-113.

Tobin, J. (1969). A general equilibrium approach to monetary theory. Journal of Money, Credit and Banking, 1(1), 15-29.

Wagner, M. (2010). The role of corporate sustainability performance for economic performance: A firmlevel analysis of moderation effects. Ecological Economics, 69(7), 1553-1560.

White, H. (1980). A heteroskedasticity-consistent covariance matrix estimator and a direct test for heteroskedasticity. Econometrica, 48(4), 817-838. 